\title{
TECHNICAL AND ORGANISATIONAL INNOVATION IN SLOVENIAN MANUFACTURING COMPANIES
}

\section{PALCIC, I.; KOREN, R. \& BUCHMEISTER, B.}

Abstract: This paper deals with the concept of technical innovation and organisational innovation in Slovenian manufacturing companies. We have conducted a survey within international project European Manufacturing Survey (EMS). We have asked manufacturing companies with at least 20 employees which technical and organisational innovation concepts they use. We have analysed the differences in the use of organisational concepts depending on the company size and technological intensity. The paper also presents the trends in use of organisational innovation concepts and future plans of companies. The results are presented with the use of descriptive statistics and they show that the use of specific technical and organisational innovation concepts in Slovenian manufacturing companies is quite diverse.

Key words: manufacturing company, technical innovation, organisational innovation, European manufacturing survey
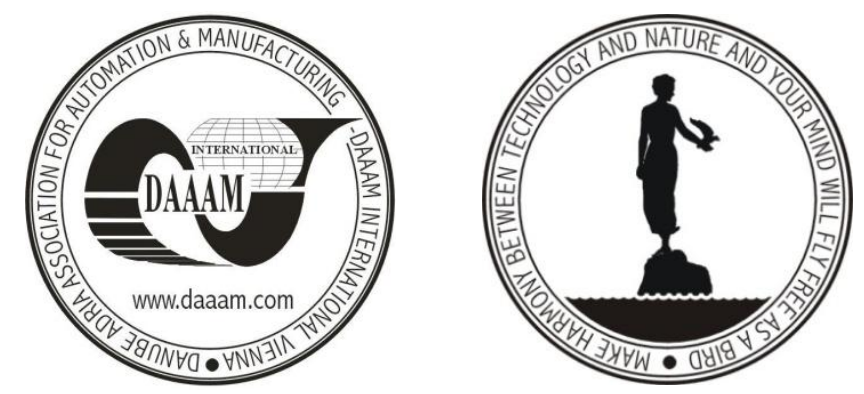

Authors' data: Assist. Prof. Dr. Sc. Palcic, I[ztok]*; Koren, R[olando]**, Assoc. Prof. Dr. Sc. Buchmeister, B[orut]*, *University of Maribor, Faculty of Mechanical Engineering, Laboratory for Production Management, Smetanova 17, SI - 2000, Maribor, Slovenia, **Premogovnik Velenje d. d., Partizanska cesta 78, 3320 Velenje, Slovenia, iztok.palcic@um.si, Rolando.Koren@rlv.si, borut.buchmeister@um.si

This Publication has to be referred as: Palcic, I[ztok]; Koren, R[olando] \& Buchmeister, B[orut] (2014). Technical and Organisational Innovation in Slovenian Manufacturing Companies, Chapter 02 in DAAAM International Scientific Book 2014, pp.019-032, B. Katalinic (Ed.), Published by DAAAM International, ISBN 978-3-901509-98-8, ISSN 1726-9687, Vienna, Austria

DOI: $10.2507 /$ daaam.scibook.2014.02 
Palcic, I.; Koren, R. \& Buchmeister, B.: Technical and Organisational Innovation i...

\section{Introduction}

Innovation, which is mostly linked to $R \& D$ of products (Bikfalvi, 2007), remains one of the leading issues in current science. There are many studies on innovation revealing that increased $\mathrm{R} \& \mathrm{D}$ activities lead to innovative products, which enable companies to achieve competitive advantages and to gain market shares (Freeman \& Soete, 1997). For present purposes, we adopted Nohria and Gulati's (1996) definition of innovation as "any policy, structure, method, or process, product or market opportunity that the manager of the innovating unit perceived to be new".

This chapter deals with two specific innovation types - technical and organisational innovation concepts in manufacturing companies, where the first aim was to map the adoption of selected innovation concepts. A bigger focus in presented research is on organisational innovation concepts, because it is a well-documented fact that that majority of research on innovation types has followed a technical focus (Camisón \& Villar-López, 2011). There are no recent studies on the use of technical innovation concepts in Slovenia, much less on organisational innovation concepts. Besides mapping the adoption of organisational innovation concepts in Slovenian manufacturing companies, we have also examined their level of use. This concepts is also hardly found in any studies. We have analysed the use of selected organisational innovation concepts also depending on the company size and technological intensity of the industries to which the manufacturing companies belong.

Our research was based on the largest European manufacturing survey (EMS), coordinated by the Fraunhofer Institute for Systems and Innovation Research - ISI from Germany. Our results are mostly from the latest round from 2012 and 2013. One of the benefits of such surveys is that enables the analysis of European manufacturing area in a longer period. Therefore, we are able to present some trends in the use of selected innovation concepts in Slovenian manufacturing companies. This is also one of the biggest contributions of our research.

The chapter is organised as follows. First we will introduce the concept of organisational innovation. The methodological section explains the characteristics of EMS and presents selected innovation concepts. After that we will present the use of these concepts in Slovenian manufacturing companies. Three subchapters will present the use of selected organisational innovation concepts and their impact on different characteristics of manufacturing companies. The chapter will conclude with the trends of organisational innovation concepts use in Slovenian manufacturing companies. Finally, a concluding discussion is provided for the findings with some managerial implications, research limitation and directions for future research.

\section{About organisational innovation}

Often innovation is synonymous with product innovation, a specific field of innovation that received considerable attention from practitioners, academics and policy makers over the last twenty years. Opposite is the case of process innovation and one of its types, namely organisational innovation or non-technical process innovation. Although considered an important contributor and trigger to the previous, 
and ultimately to company success non-technical innovations need further and deeper understanding.

Referring to many innovation researchers (Damanpour \& Evan, 1984; Totterdell et al., 2002), including Schumpeter (1934), innovation can be considered a complex phenomenon including technical (e.g., new products, new production methods) and non-technical aspects (e.g., new markets, new forms of organization) as well as product innovations (e.g., new products or services) and process innovations (e.g., new production methods or new forms of organization). Based on these considerations, there are four different types of innovations: technical product innovations, non-technical service innovations, technical process innovations, and non-technical process innovations, which are understood to be organizational innovations (Armbruster et al., 2008).

First we are going to define technical innovations - they are those that occur in the operating component and affect the technical system of an organisation. The technical system consists of the equipment and methods of operations used to transform raw materials or information into product and services (Cummings, 1978; $\mathrm{Wu}, 2014$; Kit et al., 2014). A technical innovation, therefore, can be the adoption of a new idea pertaining to a new product or a new service, or the introduction of new elements in an organisation's production process or service operations (Damanpour, 1987).

OECD Oslo Manual (2005) defines an organisational innovation as the implementation of a new organisational method in the company's business practices, workplace organisation or external relations. Organisational innovations have a tendency to increase company performance by reducing administrative and transaction costs, improving work-place satisfaction (and thus labour productivity), gaining access to non-tradable assets (such as non-codified external knowledge) or reducing costs of supplies. Organisational innovations are strongly related with all the administrative efforts of renewing the organisational routines, procedures, mechanisms, systems, etc. to promote teamwork, information sharing, coordination, collaboration, learning and innovativeness (Gunday et al., 2011).

Damanpour (1987) defines organisational innovation as the use of new managerial and working concepts and practices. When speaking about organisational innovation, Damanpour and Evan (1984) consider them to be responses to environmental change or means of bringing change in an organisation. Organisations can cope with environmental changes and uncertainties not only by applying new technologies, but also by successfully integrating technical or administrative changes into their organisational structure that improve the level of achievement of their goals (Rosner, 1968). Innovations at the organisational level may involve the implementation of a new technical idea or a new administrative idea. The adoption of a new idea in an organisation, regardless of the time of its adoption in the related organisation population, is expected to result in an organisational change that might affect the performance of that organisation. Therefore, an idea is considered new in relation to the adopting organisation, not in relation to its organisational population (Damanpour, 1987; Nicolov \& Badulescu, 2012). The administrative innovation concepts are the ones that we are going to deal with in our research. 
Often, the term "administrative innovations" is used, where these innovations are defined as those that occur in the administrative component and affect the social system of an organisation. It includes those rules, roles, procedures and structures that are related to the communication and exchange among organisational members and between the environment and organisational members. Administrative innovations constitute the introduction of a new management system, administrative process or staff development programme. An administrative innovation does not provide a new product or a new service, but it indirectly influences the introduction of products or services or the process of producing them (Kimberly \& Evanisko, 1981).

There are several ways to differentiate organisational innovation. The first possibility is into structural organisational innovations and procedural organisational innovations. Structural organisational innovations influence, change and improve responsibilities, accountability, command lines and information flows as well as the number of hierarchical levels, the divisional structure of functions $(\mathrm{R} \& \mathrm{D}$, production, human resources, financing, etc.), or the separation between line and support functions. Procedural organisational innovations affect the routines, processes and operations of a company. Thus, these innovations change or implement new procedures and processes within the company, such as simultaneous engineering or zero buffer rules (Armbruster et al., 2008).

Organisational innovation can be further differentiated along an intraorganisational and inter-organisational dimension. While intra-organisational innovations occur within an organisation or company, inter-organisational innovations include new organisational structures or procedures beyond a company's boundaries. These comprise new organisational structures in an organisation's environment, such as R\&D cooperation with customers, just-in-time processes with suppliers or customers, supply chain management practices with suppliers or customer quality audits. Intra-organisational innovations may concern particular departments or functions or may affect the overall structure and strategy of the company as a whole. Examples for intra-organisational innovations include the implementation of teamwork, quality circles, continuous improvement processes, certification of a company under ISO 9000, simultaneous (concurrent) engineering, zero-buffer principles, environmental audits, cross-functional teams (Armbruster et al., 2008).

The results of the cluster analysis on strategic management of innovation by Keupp et al. (2012) study show that organisational innovations have attracted much less attention than product innovations. Therefore, our study tries to fulfil this gap with the analysis of organisational innovation in a specific geographic area.

\section{Research methodology}

The European Manufacturing Survey (EMS), coordinated by the Fraunhofer Institute for Systems and Innovation Research - ISI, is the largest European survey of manufacturing activities. EMS questionnaire is very extensive with almost 8 pages. The survey's questions concern manufacturing strategies, the application of innovative organisational and technological concepts in production, cooperation 
issues, production off-shoring, servitisation, and questions of personnel deployment and qualification. In addition, data on performance indicators such as productivity, flexibility, quality and returns is collected. The responding companies present a cross-section of the main manufacturing industries. Included are producers of rubber and plastics, metal works, mechanical engineering, electrical engineering, textile and others. The survey is conducted among manufacturing companies (NACE codes from 15 to 37) having at least 20 employees. The main objectives of EMS project are to find out more about the use of production and information technologies, new technical and organisational approaches in manufacturing and the implementation of best management practices.

The EMS was conducted in 2003/2004 as a pilot survey in nine European countries. The survey covered Austria, Croatia, France, Germany, United Kingdom, Italy, Slovenia, Switzerland and Turkey. In the year 2006/2007 a new survey was conducted in even more European countries, where Greece, Netherlands and Spain joined the project. We received around 4000 answers from nine countries.

The next edition of the EMS was carried out in 2009. The survey became global as China and Russia joined the project team as well as Denmark and Finland. Unfortunately we did not receive data from Turkey and United Kingdom, therefore 12 countries provided data. 2009 edition of EMS added questions on energy efficiency in production.

The fourth edition of EMS started in 2012 and finished in 2013. Our family comprises now 17 countries as Czech Republic, Sweden and Brazil joined the survey. Italy, France and United Kingdom changed project partner within their country. Slovenian EMS 2012 was finished in November 2012.

Our research is mostly based on EMS data from Slovenian subsample from the years 2006, 2009 and 2012. Slovenia has always been a partner with one of the highest response rate. In 2006 we sent 474 questionnaires and received 72 answers (15,82\% response rate) In 2009 we sent 665 questionnaires and received 71 answers (10,67\% response rate). In 2012 we sent 791 questionnaires and 89 were returned $(11,25 \%$ response rate).

Figure 1 presents a structural part of question from EMS 2012 that deals with technical innovation concepts.

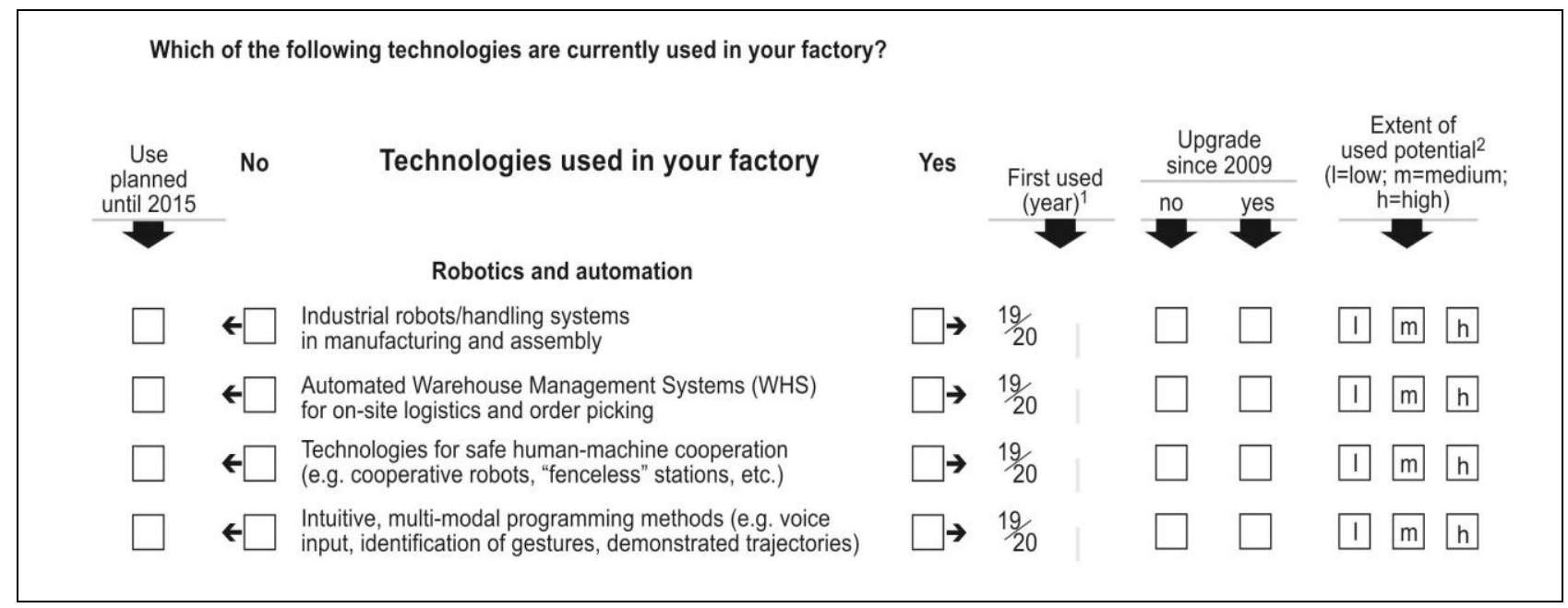

Fig. 1. Question on technical innovation concepts in EMS 2012 
Figure 2 presents a structural part of question from EMS 2012 that deals with organisational innovation concepts.

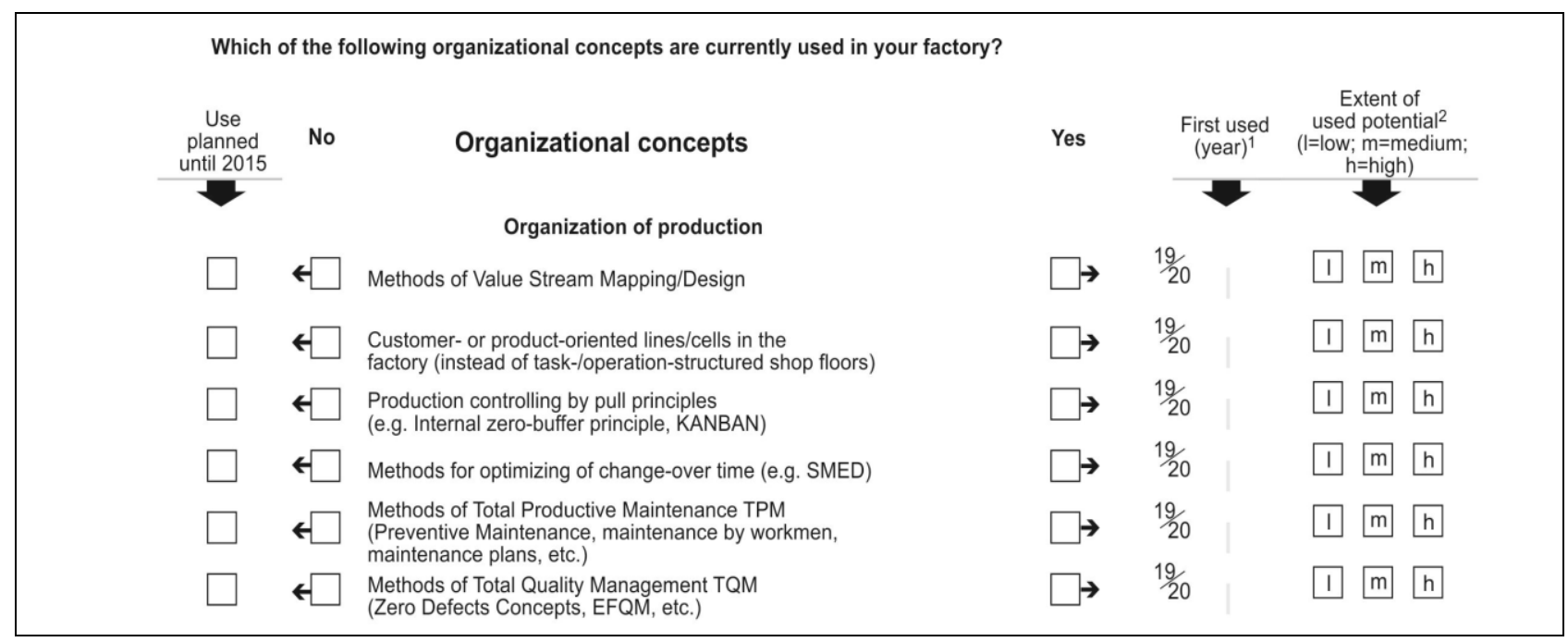

Fig. 2. Question on organisational innovation concepts in EMS 2012

For each innovation concepts we have asked for the following information:

- Use of concept (yes/no).

- Use planned in the upcoming period of three years.

- Year in which this technology has been used for the first time in your factory.

- Extent of actual utilisation compared to the most reasonable potential utilization in the factory: Extent of utilised potential "low" for an initial attempt to utilise, "medium" for partly utilised and "high" for extensive utilisation. For example - high extent of use in the case of organisational innovation concepts corresponds to at least $70 \%$ of employees to be involved in the concept use.

- Upgrade of the already implemented technical innovation concepts (technologies) in the last three years (yes/no).

In EMS 2012 we have divided 19 technical innovation concepts - technologies used in manufacturing factories - into 5 groups:

- Robotics and automation;

- Processing and production technologies;

- Digital factory/IT cross-linkage;

- Energy and resource efficiency;

- Technologies for generating renewable energy.

In EMS 2012 we have divided 22 organisational innovation concepts into 4 groups:

- Organisation of production;

- Organisation of work;

- Standards and audits;

- Human resource management. 


\section{The use of technical and organisational innovation concepts in Slovenian manufacturing companies}

First we will focus on the use of technical and organisational innovation concept in Slovenian manufacturing companies based on the last survey round.

\subsection{Frequency use of technical innovation concepts}

Table 1 presents share of Slovenian manufacturing companies who use specific technical innovation concept.

\begin{tabular}{|c|c|c|}
\hline Technology & Share & Rank \\
\hline \multicolumn{3}{|l|}{ Robotics and automation } \\
\hline Industrial robots/handling systems in manufacturing and assembly & $55,06 \%$ & 1 \\
\hline $\begin{array}{r}\text { Automated Warehouse Management Systems (WHS) for on-site logistics and order } \\
\text { picking }\end{array}$ & $15,73 \%$ & 9 \\
\hline $\begin{array}{l}\text { Technologies for safe human-machine cooperation } \\
\text { (e.g. cooperative robots, "fenceless" stations, etc.) }\end{array}$ & $6,74 \%$ & 15 \\
\hline $\begin{array}{r}\text { Intuitive, multi-modal programming methods (e.g. voice input, identification of gestures, } \\
\text { demonstrated trajectories }\end{array}$ & $4,49 \%$ & 16 \\
\hline \multicolumn{3}{|l|}{ Processing and production technologies } \\
\hline $\begin{array}{r}\text { Processing techniques for alloy construction materials (aluminium, magnesium, titanium } \\
\text { alloys, etc.) }\end{array}$ & $15,73 \%$ & 9 \\
\hline $\begin{array}{r}\text { Processing techniques for composite materials } \\
\text { (e.g. carbon fibre, fibreglass) }\end{array}$ & $3,37 \%$ & 18 \\
\hline $\begin{array}{r}\text { Manufacturing technologies for micromechanical components (micromachining, } \\
\text { lithography, microinjection) }\end{array}$ & $1,12 \%$ & 19 \\
\hline $\begin{array}{r}\text { Nano-technological production processes } \\
\text { (e.g. surface processing) }\end{array}$ & $4,49 \%$ & 16 \\
\hline \multicolumn{3}{|l|}{ Digital factory/IT cross-linkage } \\
\hline $\begin{array}{r}\text { Digital exchange of operation scheduling with data suppliers/customers (supply chain } \\
\text { management systems) }\end{array}$ & $49,44 \%$ & 2 \\
\hline $\begin{array}{r}\text { Virtual reality and/or simulation in production reconfiguration (e.g. production flows, } \\
\text { single process steps) }\end{array}$ & $21,35 \%$ & 8 \\
\hline $\begin{array}{r}\text { Virtual reality and/or simulation in product design/development (e.g. digital prototyping, } \\
\text { FEM) }\end{array}$ & $35,96 \%$ & 3 \\
\hline Product Lifecycle Management (PLM) & $13,48 \%$ & 13 \\
\hline $\begin{array}{r}\text { IT systems for storage and management of ideas } \\
\text { (idea management systems) }\end{array}$ & $25,84 \%$ & 5 \\
\hline \multicolumn{3}{|l|}{ Energy and resource efficiency } \\
\hline Dry processing/minimum lubrication & $14,61 \%$ & 11 \\
\hline Control system for shut down of machines in off-peak periods & $23,60 \%$ & 6 \\
\hline Recuperation of kinetic and process energy (waste heat recovery) & $30,34 \%$ & 4 \\
\hline Combined cold, heat and power (Bi-/Tri-generation) & $8,99 \%$ & 14 \\
\hline \multicolumn{3}{|l|}{ Technologies for generating renewable energy } \\
\hline $\begin{array}{r}\text { Technologies for power generation via solar or wind energy, hydropower, biomass or } \\
\text { geothermal energy }\end{array}$ & $22,47 \%$ & 7 \\
\hline Technologies for heat generation via solar energy, biomass or geothermal energy & $14,61 \%$ & 11 \\
\hline
\end{tabular}

Tab. 1. Share of manufacturing companies who use specific technical innovation concept - technology

The analysis shows that the most frequently used technology are industrial robots and handling systems in manufacturing and assembly, used in over $50 \%$ of Slovenian manufacturing companies. All the other technologies are present in manufacturing companies in less than $50 \%$ of cases. 
Palcic, I.; Koren, R. \& Buchmeister, B.: Technical and Organisational Innovation i...

We can observe that on average the highest usage share have the technologies from the ICT section. These technologies support manufacturing and business processes. There is an increase in the usage of technologies for direct communication with suppliers (inventory level status, production operation schedules). The same applies for software technologies for virtual reality and/or simulation in production reconfiguration and product design/development. A bit surprising is the increase in usage of IT systems for storage and management of ideas.

Slovenian manufacturing companies are obviously more and more aware of the importance of sustainable energy and resources management. We can see the increase of recuperation of kinetic and process energy technologies and technologies for power generation via different means. Still, the share of manufacturing companies which implement these technologies is rather low (less than 25\%). Analysis also shows a very low share of manufacturing companies using processing techniques for composite materials and manufacturing technologies for micromechanical components and nano-technological production processes.

Table 2 shows that in top ten most frequently used organisational innovation concepts we can find all five organisational innovation concepts from the "Organisation of work" and only one concept from "Standards and audits" group ISO 9000 (quality management audit). Teamwork in manufacturing and assembly is one of the most frequently used methods of work organisation, as it is implemented in 8 out of 10 manufacturing companies. The same applies for standardised and detailed work instructions. These two concepts are followed by ISO 9000 (quality management audit) with the identical share of use. All the other organisational innovation concepts have much smaller share of use; the majority of them is implemented in less than $50 \%$ of manufacturing companies.

Regarding the most used organisational concepts our results are in line with other studies' findings. For example, the latest EuroFound (2012) report on work organisation shows data on the proliferation of teamwork in Europe and finds and overall EU figure of $68 \%$ the employed work in some kind of team. This finding is also in line with the most recent ISO statistics regarding ISO 9000. Training programmes are one of the most spread and regular HRM policies in business practice situating fourth in our ranking of most often used organisational concepts, an indicator of quality of work and employment. Its importance is crucial taking into account the long-standing European policy goal to move towards 'the most competitive knowledge-based economy in the world'.

A bit surprising is the low share of manufacturing companies who claim they have implemented Six Sigma principles that are so popular in the recent years (e. g. lean production). The same quite low share of $14 \%$ is also evident for methods of value stream mapping that can also help in implementation of lean processes. ISO 14031 certification (environmental audit) and ISO 50001:2011 certification (energy audit) have also extremely low share of usage. Except for employee training for skills related to creativity and innovation (with 50\% share of use) from the "Human resource management" group all the other concepts from this group show a pretty low share of use. 


\begin{tabular}{|c|c|c|}
\hline DAAAM INTERNATIONAL SCIENTIFIC BOOK 2014 & & Chapter 02 \\
\hline Organisational concept & Share & Rank \\
\hline Organisation of production & & \\
\hline Methods of Value Stream Mapping/Design & $13,48 \%$ & 19 \\
\hline $\begin{array}{r}\text { Customer- or product-oriented lines/cells in the factory } \\
\text { (instead of task-/operation-structured shop floors) }\end{array}$ & $28,09 \%$ & 12 \\
\hline $\begin{array}{r}\text { Production controlling by pull principles } \\
\text { (e.g. Internal zero-buffer principle, KANBAN) }\end{array}$ & $26,97 \%$ & 13 \\
\hline Methods for optimizing of change-over time (e.g. SMED) & $19,10 \%$ & 15 \\
\hline $\begin{array}{r}\text { Methods of Total Productive Maintenance TPM (Preventive Maintenance, maintenance } \\
\text { by workmen, maintenance plans) }\end{array}$ & $49,44 \%$ & 6 \\
\hline $\begin{array}{r}\text { Methods of Total Quality Management TQM } \\
\text { (Zero Defects Concepts, EFQM, etc.) }\end{array}$ & $40,45 \%$ & 8 \\
\hline Organisation of work & & \\
\hline Method of 5S ("work place appearance and cleanliness") & $52,81 \%$ & 4 \\
\hline Standardised and detailed work instructions ("standard work") & $78,65 \%$ & 1 \\
\hline $\begin{array}{r}\text { Integration of tasks (planning, operating or controlling functions with the machine } \\
\text { operator) }\end{array}$ & $40,45 \%$ & 8 \\
\hline $\begin{array}{r}\text { Methods for continuous improvement process } \\
\text { (CIP, KAIZEN, quality circle, etc.) }\end{array}$ & $43,82 \%$ & 7 \\
\hline Team work in manufacturing and assembly & $78,65 \%$ & 1 \\
\hline Standards and audits & & \\
\hline Visual management (display board in production for work processes and work status) & $25,84 \%$ & 14 \\
\hline ISO 9000 et seq. certification (quality management audit) & $77,53 \%$ & 3 \\
\hline Six Sigma & $13,48 \%$ & 19 \\
\hline ISO 14031 certification (environmental audit) & $16,85 \%$ & 18 \\
\hline ISO 50001:2011 certification (energy audit) & $2,25 \%$ & 22 \\
\hline $\begin{array}{r}\text { Methods of investment evaluation, taking into account the entire life cycle costs (e.g. } \\
\text { Total Cost of Ownership TCO) }\end{array}$ & $5,62 \%$ & 21 \\
\hline Human resource management & & \\
\hline $\begin{aligned} \text { Formalized sessions for idea generation among employees } \\
\end{aligned}$ & $34,83 \%$ & 11 \\
\hline $\begin{array}{r}\text { Instruments to maintain elderly employees or their knowledge in the factory (e.g. } \\
\text { training programs, incentive systems, or similar) }\end{array}$ & $17,98 \%$ & 16 \\
\hline $\begin{array}{r}\text { Working time specifically dedicated for creativity and innovation (incl. e.g. changes in } \\
\text { production processes) }\end{array}$ & $17,98 \%$ & 16 \\
\hline $\begin{array}{r}\text { Talent development program (e.g. promotion of young talents for senior posts, special } \\
\text { training programs, etc.) }\end{array}$ & $39,33 \%$ & 10 \\
\hline $\begin{array}{r}\text { Employee training for skills related to creativity and innovation (e.g. problem solving, } \\
\text { idea generation or brainstorming) }\end{array}$ & $52,81 \%$ & 4 \\
\hline
\end{tabular}

Tab. 2. Share of manufacturing companies who use specific organisational innovation concept

\subsection{Extent of use of organisational innovation concepts}

As we have already mentioned we have also analysed organisational innovation concepts based on the extent of use (low, medium, high). This assessment is partly subjective, but still provides some interesting information. Figure 3 depicts extent of use of the top 10 organisational innovation concepts (see Table 2). Analysis showed that only ISO 9000 standard is mostly implemented with a high extent of usage. We can see that ISO 9000 standard is very frequently implemented in Slovenian manufacturing companies and on the top of that its extent of use is mostly high. Only $10 \%$ of manufacturing companies with ISO 9000 standard implemented consider its extent of use low. All the other nine organisational innovation concepts have predominant medium extent of use (except standardised work instructions). A very small share of manufacturing companies with implemented HRM programmes (employee training for skills in creativity and talent development program) claim that their extent of use is high. 
Palcic, I.; Koren, R. \& Buchmeister, B.: Technical and Organisational Innovation i...

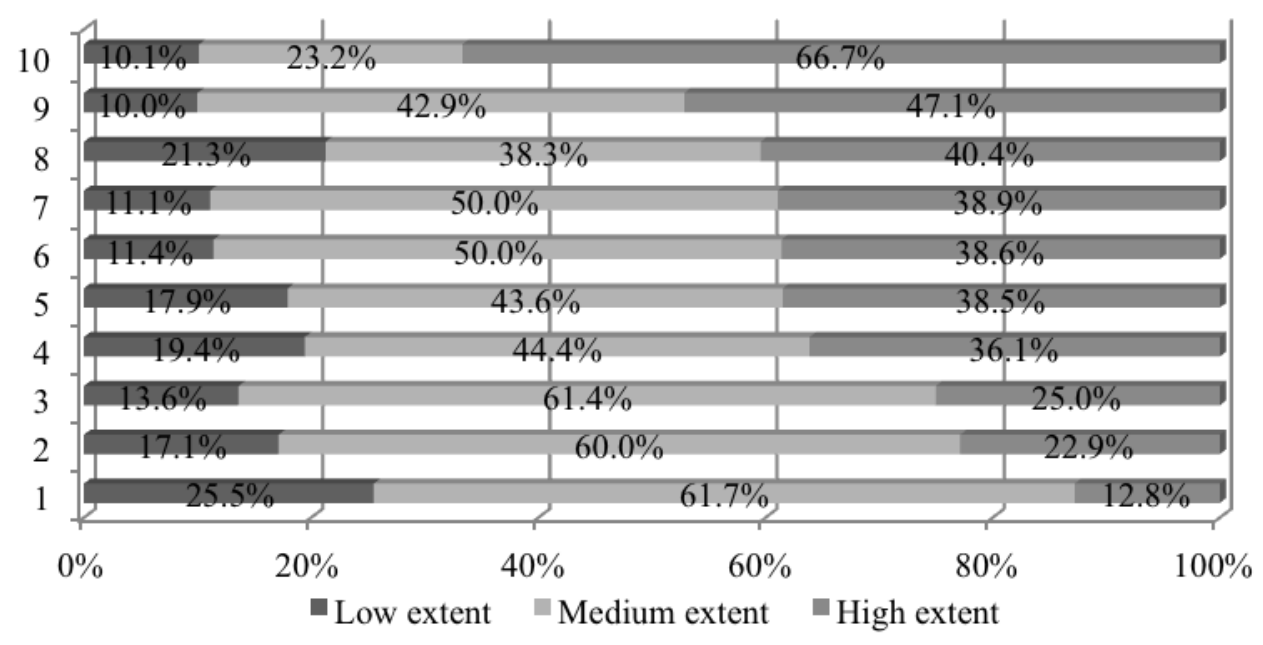

Fig. 3. Organisational innovation concept extent of use

Numbers on the ordinate axis in Fig. 3 present analysed organisational innovation concepts:

1. Employee training for skills in creativity

2. Talent development program

3. Total Productive Maintenance TPM

4. Total Quality Management TQM

5. Continuous improvement process

6. Team work in manufacturing

7. Integration of tasks

8. Method of $5 \mathrm{~S}$

9. Standardised work instructions

10. ISO 9000 (quality management audit)

\subsection{Use of organisational innovation concepts and company size}

Our analysis about the diffusion of organisational innovation concepts has been upgraded with some additional insights. First we have analysed the relationship between innovation concepts diffusion and company size (small, medium and large based on number of employees). As already mentioned we have included in our survey only companies with 20 employees and more. Still, it was a bit surprising that the largest share of respondents is from middle sized companies (around 50\%) and that the share of large companies was the same as for the small companies (each around $25 \%$ ).

We have selected 5 most frequently used organisational innovation concepts: standardized work instructions, team work in production, ISO 9000 (quality management audit), employee training for skills in creativity and $5 \mathrm{~S}$. 


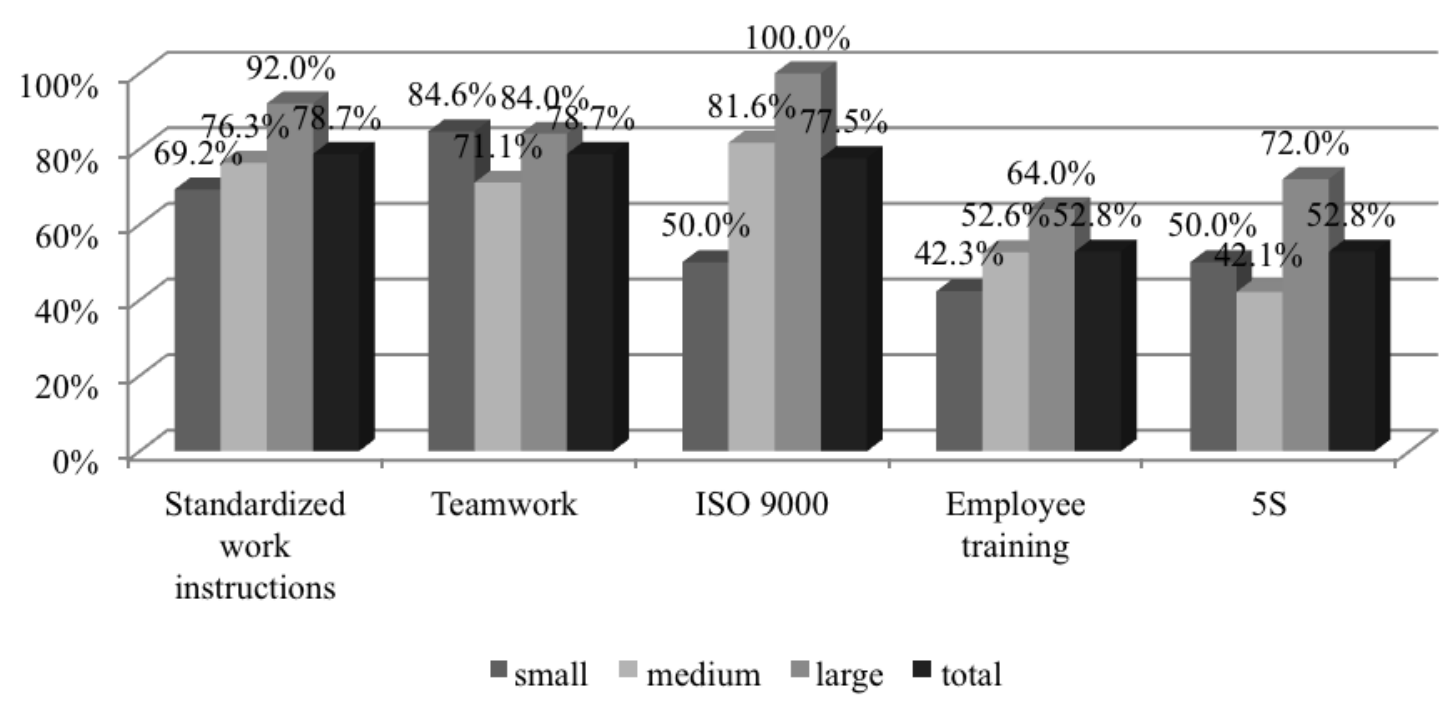

Fig. 4. The share of organisational innovation concepts and the manufacturing company size

The pattern of most widely used organisational innovation concepts diffusion is similar quite expected. Large manufacturing companies are on average again the ones with the highest share of use, but the differences between companies (based on their size) are much smaller. An interesting exception is teamwork in production with the highest share in small companies. All large manufacturing companies have ISO 9000 standard implemented.

\subsection{Use of organisational innovation concepts and technological intensity}

We have classified manufacturing companies based on technological intensity, using OECD classification for high-, medium- and low-tech sectors. We have formed two groups:

- low-medium technological intensity - LMT, including companies from low-tech and medium-low-tech industries - NACE codes 13, 14, 15, 22, 23, 24, 25 and 32 ;

- medium-high technological intensity - MHT, including companies from medium-high-tech and high-tech industries - NACE codes 26, 27, 28, 29 and 30 .

We have used the same organisational innovation concepts as in previous subchapter. The results show that technological intensity of manufacturing companies has no direct impact on the share of companies that adopted organisational innovation concepts. They are mostly more often implemented in MHT, exception is teamwork and TQM (see Fig. 5). 
Palcic, I.; Koren, R. \& Buchmeister, B.: Technical and Organisational Innovation i...

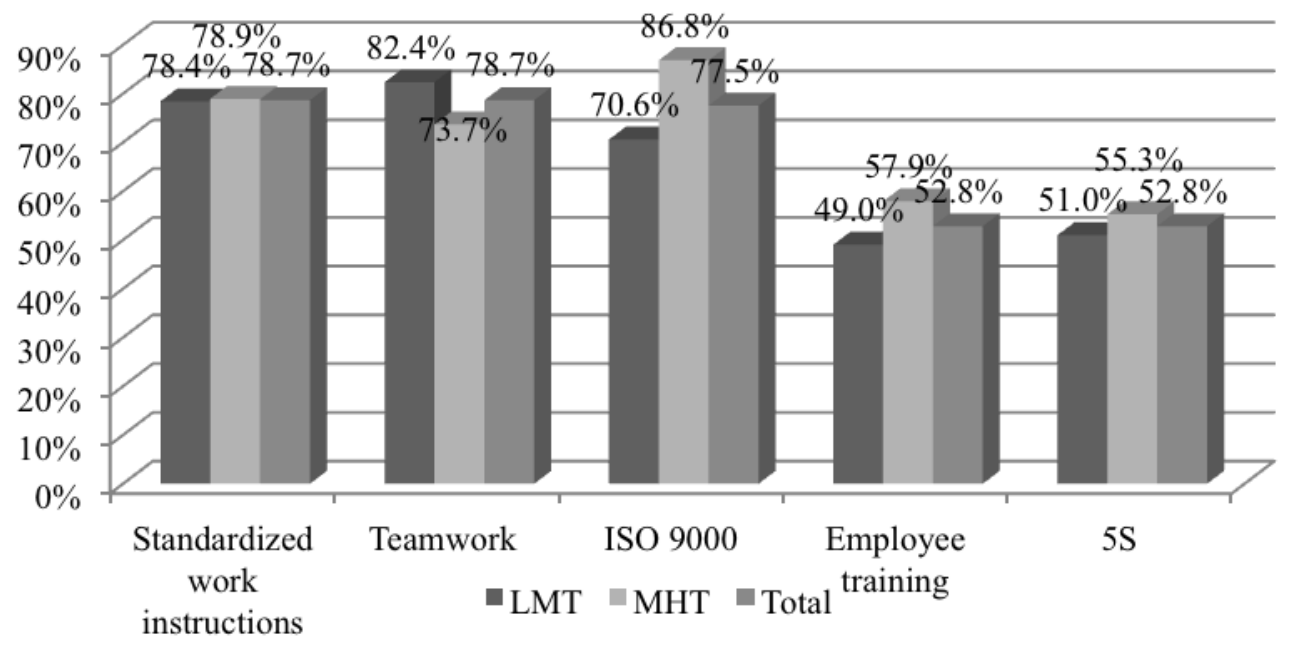

Fig. 5. The share of organisational innovation concepts and technological intensity

\subsection{Trends in using organisational innovation concepts in Slovenian manufacturing companies}

This paper is concluded with the analysis of cooperation trends in Slovenian manufacturing companies based on the data from EMS 2003, 2006, 2009 and 2012. Four EMS rounds enable to monitor different trends in the innovation concepts use in the last decade. Over the years we have changed our questionnaire and updated the list of technical and organisational innovation concepts. Only 3 organisational innovation concepts are a part of survey in all four rounds and for these concepts we present changes in their adoption.

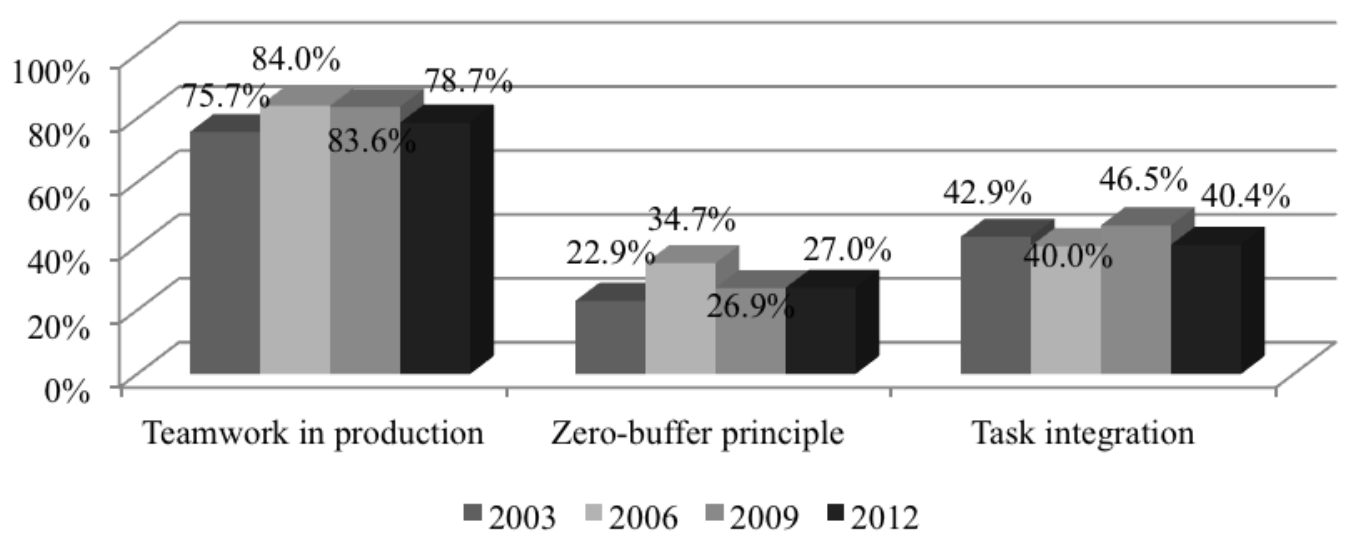

Fig. 6. The use of selected organisational innovation concepts in the period 20032013

Figure 6 presents three selected organisational innovation concepts that have been observed in the last 10 years: teamwork in production, zero-buffer principle and task integration. Teamwork has always been most widely used organisational innovation concept (around 80\%). More interesting is zero-buffer principle with its 
peak in 2006-07, when a bit more than one third of the companies implemented the concept. After that the percentage has dropped to every fourth company. The share of this concept is in general pretty low, which means that many companies are still not aware about the importance of effective inventory management. On the other hand Slovenian manufacturing companies are mostly suppliers to foreign OEMs, and that makes it hard to focus on optimal inventory levels in their production facilities in order to be dependable partner. The task integration concept does not present any special usage pattern, as the concept is implemented in around $40 \%$ companies through the years.

\section{Conclusion}

In this chapter we have analysed how widely selected technical and organisational concepts are used in Slovenian manufacturing companies, what is the extent of their use, what differences exist in the use and extent of use of these concepts and which are the characteristics of the adopters (company size, technological intensity).

Looking at specific technical and organisational innovation concepts in EMS 2012 we can conclude two things:

- The use of several technologies that are considered in European industrial strategy until 2020 as key technologies is in Slovenian manufacturing companies very low.

- Slovenian manufacturing companies have an extremely low share of organisational innovation concepts that deal with human resource management issues. When implemented these concepts have also low extent of use. This could mean that these companies do not develop their talents (employees) in a sufficient manner.

As with all research, the present study has certain limitations. The first limitation of the study is its focus on specifically selected industries and manufacturing companies with at least 20 employees. The next limitation is that we only focused on Slovenian manufacturing companies, where comparison with other European is very desirable in the future. Future lines of research could propose relationship between the number and the extent of use of technical and organisational innovation concepts and company financial and R\&D performance. Nevertheless, we believe that results of the study enrich the literature on the adoption of technical and organisational innovation concepts and depict the current situation in a selected part of Europe.

\section{References}

Armbruster, H.; Bikfalvi, A.; Kinkel, S. \& Lay, G. (2008). Organizational innovation: The challenge of measuring non-technical innovation and large-scale surveys.

Technovation, Vol. 28, 644-657

Bikfalvi, A. (2007). Innovation, Entrepreneurship and outsourcing: essays on the use of knowledge in business environments, doctoral dissertation, Girona 
Palcic, I.; Koren, R. \& Buchmeister, B.: Technical and Organisational Innovation i...

Camisón, C. \& Villar-López, A. (2011). Non-technical innovation: Organizational memory and learning capabilities as antecedent factors with effects on sustained competitive advantage. Industrial Marketing Management, Vol. 40, 1294-1304

Cummings, T. G. (1978). Self-regulating work groups: a socio-technical Systems Approach. Academy of Management Review, Vol. 3, 625-634

Damanpour, F. \& Evan, W. M. (1984). Organizational innovation and performance: the problem of "Organizational Lag". Administrative Science Quarterly, Vol. 29, 392-409

Damanpour, F. (1987). The adoption of technological, administrative and ancillary innovations: impact of organizational factors. Journal of Management, Vol. 13, No. 4, 675-688

Freeman, C. \& Soete, L. (1997). The Economics of Industrial Innovation, Pinter Publisher, London

Gunday, G.; Ulusoy, G.; Kilic, K. \& Alpkan, L. (2011). Effects of innovation types on firm performance. International Journal of Production Economics, Vol. 133, 662676

Keupp, M. M.; Palmie, M. \& Gassmann, O. (2011). The Strategic Management of Innovation: A Systematic Review and Paths for Future Research. International Journal of Management Reviews, Vol. 14, 367-390

Kim, S. T.; Hong, S. R. \& Kim, C. O. (2014). Product Attribute Design Using an Agent-Based Simulation of an Artificial Market, International Journal of Simulation Modelling, Vol. 13, No. 3, 288-299

Kimberly, J. R. \& Evanisko, M. (1981). Organizational innovation: The influence of individual, organizational, and contextual factors on hospital adoption of technological and administrative innovations. Academy of Management Journal, Vol. $24,689-713$

Nicolov, M. \& Badulescu, A. D. (2012). Different types of innovations modelling, Annals of DAAAM for 2012 \& Proceedings of the 23rd International DAAAM Symposium, Katalinic, B. (Ed.), pp. 1071-1074, ISBN 978-3-901509-91-9, November 2012, DAAAM International, Vienna, Austria

Nohria, N. \& Gulati, R. (1996). Is slack good or bad for innovation. Academy of Management Journal, Vol. 39, 1245-1264

OECD. (2005). Oslo manual. Guidelines for collecting and interpreting innovation data (3rd ed.), OECD EUROSTAT, Paris

Rosner, M. M. (1968). Economic determinants of organisational innovation. Administrative Science Quarterly, Vol. 12, 614-625

Schumpeter, J. (1934). The Theory of Economic Development, Harvard University Press, Cambridge, Massachusetts

Totterdell, P.; Leach, D.; Birdi, K.; Clegg, C. \& Wall, T. (2002). An investigation of the contents and consequences of major organizational innovations. International Journal of Innovation Management, Vol. 6, No. 4, 343-368

Wu, G.-D. (2014). Project-Based Supply Chain Cooperative Incentive Based on Reciprocity Preference. International Journal of Simulation Modelling, Vol. 13, No. $1,102-115$ 